\title{
The Structure and Properties of Copolyaspartate II. Copoly(ethyl-L-aspartate-benzyl-L-aspartate) and Copoly(methyl-L-aspartate-benzyl-L-aspartate)
}

\author{
Yoshiharu Tsujita, Mikio Fukagawa, ${ }^{*}$ and Ichitaro Uematsu* \\ Department of Polymer Engineering, Nagoya Institute of Technology, \\ Gokiso, Showa-ku, Nagoya 466, Japan \\ * Department of Polymer Chemistry, Tokyo Institute of Technology, \\ Meguro-ku, Tokyo 152, Japan
}

(Received January 30, 1982)

\begin{abstract}
Copoly(alkyl(ethyl or methyl)-L-aspartate-benzyl-L-aspartate) alkylated less than $20 \%$ (e.g., E-1) transformed at $127^{\circ} \mathrm{C}$ into the $\omega$ helix accompanied by the incorporation of a small amount of alkyl-L-aspartate into the $\omega$ helix of the benzyl-L-aspartate. Only the benzyl-Laspartate of copolyaspartates with alkylation from 20 to $60 \%$ transformed into the $\omega$ helix in the temperature range from 100 to $130^{\circ} \mathrm{C}$, and the rest of the alkyl-L-aspartate still remaining in the $\alpha$ helix form. That is, copolyaspartates exist as mixtures of the $\alpha$ helix and the $\omega$ helix and packing modes of helices must change in the temperature range from 100 to $130^{\circ} \mathrm{C}$. It was found that the formation of the stacks between benzyl and ethyl or methyl groups could not take place, in contrast to the formation of stacks between benzyl and butyl groups. For alkylation more than $60 \%$, benzyl$\mathrm{L}$-aspartate did not form either $\omega$ helices nor stacks and thus there was no $\alpha-\omega$ transition. All copolyaspartates synthesized here transformed into the $\beta$ form in the vicinity of $200^{\circ} \mathrm{C}$. Copolyaspartate with alkylation at about $80 \%$ exhibited a much higher transition temperature than poly $(\beta$ benzyl-L-aspartate). The $\alpha$ helices of $\operatorname{poly}(\beta$-ethyl-L-aspartate $)$ and poly $(\beta$-methyl-L-aspartate $)$ are thus considered much more stable than the $\omega$ helix of poly( $\beta$-benzyl-L-aspartate).

KEY WORDS Transition / $\omega$-Helix / $\beta$-Form / Stack / Copoly(ethyl-Laspartate-benzyl-L-aspartate) / Copoly(methyl-L-aspartate-benzyl-Laspartate) /
\end{abstract}

It is well known that poly ( $\beta$-benzyl-L-aspartate) (PBLAsp) forms a rather unstable left handed $\alpha$ helix by the interaction of the main chain with the side chain (competitive hydrogen bonding) and that the $\alpha$ helix of PBLAsp is transformed into the $\omega$ helix in a solid state by heat treatment. ${ }^{1}$ Bradbury et $a l$. investigated the helix stability of $\operatorname{poly}(\beta$ - $n$-alkylL-aspartate $)^{2,3}$ and found that an ester group of polyaspartate determines the helix sense. For example, both PBLAsp and poly( $\beta$-methyl-L-aspartate) are left handed $\alpha$ helices. On the other hand, poly( $\beta$-ethyl-L-aspartate), poly( $\beta$ - $n$-propyl-L-aspartate), and $\operatorname{poly}(\beta$-butyl-L-aspartate) are right handed $\alpha$ helices. A reversal in helix sense is expected by ethylation or propylation, or butylation of the benzyl groups of PBLAsp. The authors ${ }^{4}$ reported in the preceding paper that copoly(butyl-L-aspartatebenzyl-L-aspartate) butylated to a certain degree causes a reversal in the helix sense, accompanied by an $\alpha-\omega$ transition and that the $\omega$ helix of copoly(butyl-L-aspartate-benzyl-L-aspartate) forms stacks between the benzyl and butyl groups or between the butyl groups.

In the present paper, formation of the $\omega$ helix and a reversal in helix sense were investigated for two kinds of copolyaspartates having various degrees of ethylation or methylation of PBLAsp. Furthermore, the viscoelastic and thermal behavior of these copolyaspartates and the $\omega-\beta$ transformation were studied.

\section{EXPERIMENTAL}

The same PBLAsp specimen as in the preceding paper $^{4}$ was used for alkylation. Copoly(ethyl-Laspartate-benzyl-L-aspartate) 
Table I. Conditions of ethylation

\begin{tabular}{|c|c|c|c|c|c|c|}
\hline \multirow{2}{*}{ Sample } & $\begin{array}{l}\text { Content of } \\
\text { PBLAsp }\end{array}$ & $\begin{array}{c}\text { Content of } \\
\mathrm{CHCl}_{3}\end{array}$ & $\begin{array}{c}\text { Content of } \\
\mathrm{H}_{2} \mathrm{SO}_{4}\end{array}$ & $\begin{array}{l}\text { Reaction } \\
\text { time }\end{array}$ & Ethanol & $\begin{array}{l}\text { Degree of } \\
\text { ethylation }\end{array}$ \\
\hline & g & $\mathrm{ml}$ & $\mathrm{ml}$ & $\mathrm{h}$ & $\mathrm{ml}$ & $\%$ \\
\hline E-1 & 0.4 & 100 & 0.2 & 70 & 40 & 16.6 \\
\hline E-2 & 0.4 & 100 & 0.2 & 98 & 50 & 34.8 \\
\hline E-3 & 0.4 & 100 & 0.2 & 165 & 60 & 42.3 \\
\hline E-4 & 0.4 & 100 & 1.0 & 168 & 60 & 66.0 \\
\hline E-5 & 0.4 & 100 & 1.5 & 166 & 60 & 76.2 \\
\hline
\end{tabular}

Table II. Conditions of methylation

\begin{tabular}{|c|c|c|c|c|c|c|}
\hline \multirow{2}{*}{ Sample } & $\begin{array}{l}\text { Content of } \\
\text { PBLAsp }\end{array}$ & $\begin{array}{l}\text { Content of } \\
\mathrm{CHCl}_{3}\end{array}$ & $\begin{array}{c}\text { Content of } \\
\mathrm{H}_{2} \mathrm{SO}_{4}\end{array}$ & $\begin{array}{l}\text { Reaction } \\
\text { time }\end{array}$ & Methanol & $\begin{array}{l}\text { Degree of } \\
\text { methylation }\end{array}$ \\
\hline & $\mathrm{g}$ & $\mathrm{ml}$ & $\mathrm{ml}$ & $\mathrm{h}$ & $\mathrm{ml}$ & $\%$ \\
\hline M-1 & 0.4 & 100 & 0.2 & 20 & 30 & 21.0 \\
\hline M-2 & 0.4 & 100 & 0.2 & 40 & 30 & 28.0 \\
\hline M-3 & 0.4 & 100 & 0.2 & 70 & 30 & 66.3 \\
\hline M-4 & 0.4 & 100 & 0.2 & 168 & 30 & 84.4 \\
\hline
\end{tabular}

BLAsp)) and copoly(methyl-L-aspartate-benzyl-Laspartate) (copoly(MLAsp-BLAsp)) were prepared by ethylation of PBLAsp and methylation of PBLAsp, respectively. Reaction conditions and the degree of alkylation are shown in Table I for copoly(ELAsp-BLAsp) and in Table II for copoly(MLAsp-BLAsp). Preparation of solid films and experimental methods are described in the preceding paper. ${ }^{4}$

\section{RESULTS AND DISCUSSION}

\section{Copoly (ethyl-L-aspartate-benzyl-L-aspartate) \\ Infrared Absorption Spectroscopy}

Characteristic band positions of polypeptides provide information on the conformation of the polypeptide molecule, e.g., $\alpha$ helix, $\omega$ helix, and $\beta$ form and the helix sense. Tables III, IV, and V give characteristic band positions observed for the as-cast films, and the films annealed at $150^{\circ} \mathrm{C}$ and $210^{\circ} \mathrm{C}$, respectively. Abbreviations E-1 -5 were utilized, depending upon degree of ethylation of copoly(ELAsp-BLAsp) as shown in Table I. Judging from the helix sense shown in Table III, copoly(ELAspBLAsp) is a mixture of right handed and left handed helices. The right handed helix is apt to predominate even at a low degree of ethylation. According
Table III. Band positions of as-cast films $\left(\mathrm{cm}^{-1}\right)^{\mathrm{a}}$

\begin{tabular}{clll}
\hline & Ester C $=\mathrm{O}$ & Amide I & Amide II \\
\hline PBLAsp $(\alpha)$ & 1735 & 1663 & 1553 \\
E-1 & $1738^{\text {sh }}$ & $1660^{\text {sh }}$ & 1550 \\
E-2 & $1736^{\text {sh }}$ & $1659^{\text {sh }}$ & 1551 \\
E-3 & $1738^{\text {sh }}$ & $1660^{\text {sh }}$ & 1550 \\
E-4 & $1738^{\text {sh }}$ & $1660^{\text {sh }}$ & 1550 \\
E-5 & $1738^{\text {sh }}$ & $1660^{\text {sh }}$ & 1550 \\
\hline
\end{tabular}

a sh, shoulder is included.

Table IV. Band positions of films annealed at $150^{\circ} \mathrm{C}\left(\mathrm{cm}^{-1}\right)^{\mathrm{a}}$

\begin{tabular}{cclc}
\hline & Ester C=O & Amide I & Amide II \\
\hline PBLAsp $(\omega)$ & 1730 & 1676 & 1533 \\
E-1 & 1723 & $1665^{\text {sh }}$ & 1533 \\
E-2 & $1724^{\text {sh }}$ & $1660^{\text {sh }}$ & 1533,1549 \\
E-3 & $1723^{\text {sh }}$ & $1659^{\text {sh }}$ & 1534,1550 \\
E-4 & 1736 & 1659 & 1549 \\
E-5 & 1736 & 1659 & 1549 \\
\hline
\end{tabular}

a sh, shoulder is included.

to a study on helix sense by Bradbury et al., ${ }^{2}$ copoly(ELAsp-BLAsp) takes on a left handed helix conformation below $35 \%$ ethylation and 
The Structure and Properties of Copolyaspartate II.

Table V. Band positions of films annealed at $210^{\circ} \mathrm{C}\left(\mathrm{cm}^{-1}\right)^{\mathrm{a}}$

\begin{tabular}{ccll}
\hline & Ester C $=\mathrm{O}$ & Amide I & Amide II \\
\hline PBLAsp $(\beta)$ & 1725 & 1634 & 1530 \\
E-1 & 1728 & $1636^{\text {sh }}$ & $1533^{\text {sh }}$ \\
E-2 & 1727 & $1636^{\text {sh }}$ & $1533^{\text {sh }}$ \\
E-3 & 1724 & $1634^{\text {sh }}$ & 1530 \\
E-4 & 1724 & $1633^{\text {sh }}$ & 1529 \\
E-5 & 1725 & $1633^{\text {sh }}$ & 1528 \\
\hline
\end{tabular}

a sh, shoulder is included.

right handed helix conformation above $35 \%$ ethylation in a chloroform solution. Comparing our results with those by Bradbury et al., it is suggested that the reversal in helix sense occurs at a lower degree of ethylation in the solid state than in solution.

The band position of the E-1 films annealed at $150^{\circ} \mathrm{C}$ showed the existence of the $\omega$ helix. Therefore, the $\alpha-\omega$ transition occurs in the E-1 films by annealing $\left(150^{\circ} \mathrm{C}\right)$ and hence stacks between benzyl groups or between benzyl and ethyl groups must be formed. Relatively small amounts of ethylL-aspartate were incorporated into the $\omega$ helix consisting of benzyl-L-aspartate. E-2 films annealed at $150^{\circ} \mathrm{C}$ were a mixture of $\alpha$ and $\omega$ helices, as seen especially from Amide II band. A certain length of benzyl-L-aspartate sequence in E-2, 3 might, in part, be transformed into the $\omega$ helix. The ethyl-Laspartate and the benzyl-L-aspartate with a short sequence cannot transform into the $\omega$ helix, but remain in the $\alpha$ helix. It was found that stacks between the benzyl and ethyl groups could not be formed in the case of the E-2, 3 films and that the coexistence of $\alpha$ and $\omega$ helices was possible within a single molecule. The E-4, 5 films could not transform to a further extent by annealing at $150^{\circ} \mathrm{C}$, but remained in the $\alpha$ helix. Because of relatively small amounts of benzyl-L-aspartate, the formation of stacks between benzyl groups and between benzyl and ethyl groups is improbable. Consequently, there is no transition of the $\alpha$ helix.

All copoly(ELAsp-BLAsp)s transformed into the $\beta$ form, judging from Amide I band (Table V).

\section{$X$-Ray Diffraction Analysis}

The spacings observed in X-ray diffraction photographs of all copoly(ELAsp-BLAsp)s are given in Table VI. All specimens of the as-cast
Table VI. Spacings ( $\AA$ ) observed in X-ray diffraction photographs of PBLAsp and copoly(ELAsp-BLAsp)

\begin{tabular}{cclc}
\hline & $\begin{array}{c}\text { As-cast } \\
\text { films }\end{array}$ & $\begin{array}{c}\text { Films } \\
\text { annealed } \\
\text { at } 150^{\circ} \mathrm{C}\end{array}$ & $\begin{array}{c}\text { Films } \\
\text { annealed } \\
\text { at } 210^{\circ} \mathrm{C}\end{array}$ \\
\hline PBLAsp & 13.2 & 13.9 & 17.1 \\
E-1 & 13.2 & $13.8(14.7)$ & 15.7 \\
E-2 & 12.8 & 17.2 & 15.5 \\
E-3 & 12.8 & 16.2 & 15.4 \\
E-4 & 12.2 & 12.2 & 14.1 \\
E-5 & 11.8 & 11.7 & - \\
\hline
\end{tabular}

films, including PBLAsp, showed a low degree of crystallinity. The spacings of the as-cast films become shorter than those of copoly(butyl-L-aspartate-benzyl-L-aspartate) as the degree of ethylation increases, reflecting the shorter side chain of the ethyl group.

Only the E-1 films annealed at $150^{\circ} \mathrm{C}$ had nearly the same spacings as the $\omega$ helix of PBLAsp (13.9 $)$ and showed a relatively high degree of crystallinity. The $\alpha-\omega$ transition of copoly(ELAsp-BLAsp) (E-1) was found to be accompanied by a transformation from hexagonal to tetragonal packing, judging from the other diffractions. ${ }^{4}$ The spacings of E-2, 3 films annealed at $150^{\circ} \mathrm{C}$ corresponded to neither the $\alpha$ helix nor the $\omega$ helix, but were rather large; these films were very poorly crystalline. The E-2, 3 helices consisting of both the $\alpha$ and $\omega$ helices in a single chain were packed sparsely, suggesting an irregularity about a junction of the $\alpha$ helix and the $\omega$ helix. Therefore the unit cell of the E-2, 3 films annealed at $150^{\circ} \mathrm{C}$ may be considered to be in a rather large hexagonal array. The E-4, 5 films annealed at $150^{\circ} \mathrm{C}$ were thermally stable up to $150^{\circ} \mathrm{C}$ and hence the spacings remained unchanged by annealing. The films annealed at $210^{\circ} \mathrm{C}$ transformed into the $\beta$ form as seen from the intersheet spacing in Table VI.

\section{Dynamic Viscoelastic Behavior}

The dynamic modulus $E^{\prime}$ and $\tan \delta$ at $110 \mathrm{~Hz}$ are shown as functions of temperature in Figure 1. Viscoelastic behavior can be classified into three patterns E-1, E-2, 3, and E-4, 5, on the basis of the results of infrared absorption spectroscopy and $\mathrm{X}$-ray diffraction analysis.

For E-1, the tan $\delta$ peak appears near $110^{\circ} \mathrm{C}$ and a corresponding considerable decrease in $E^{\prime}$ is ob- 


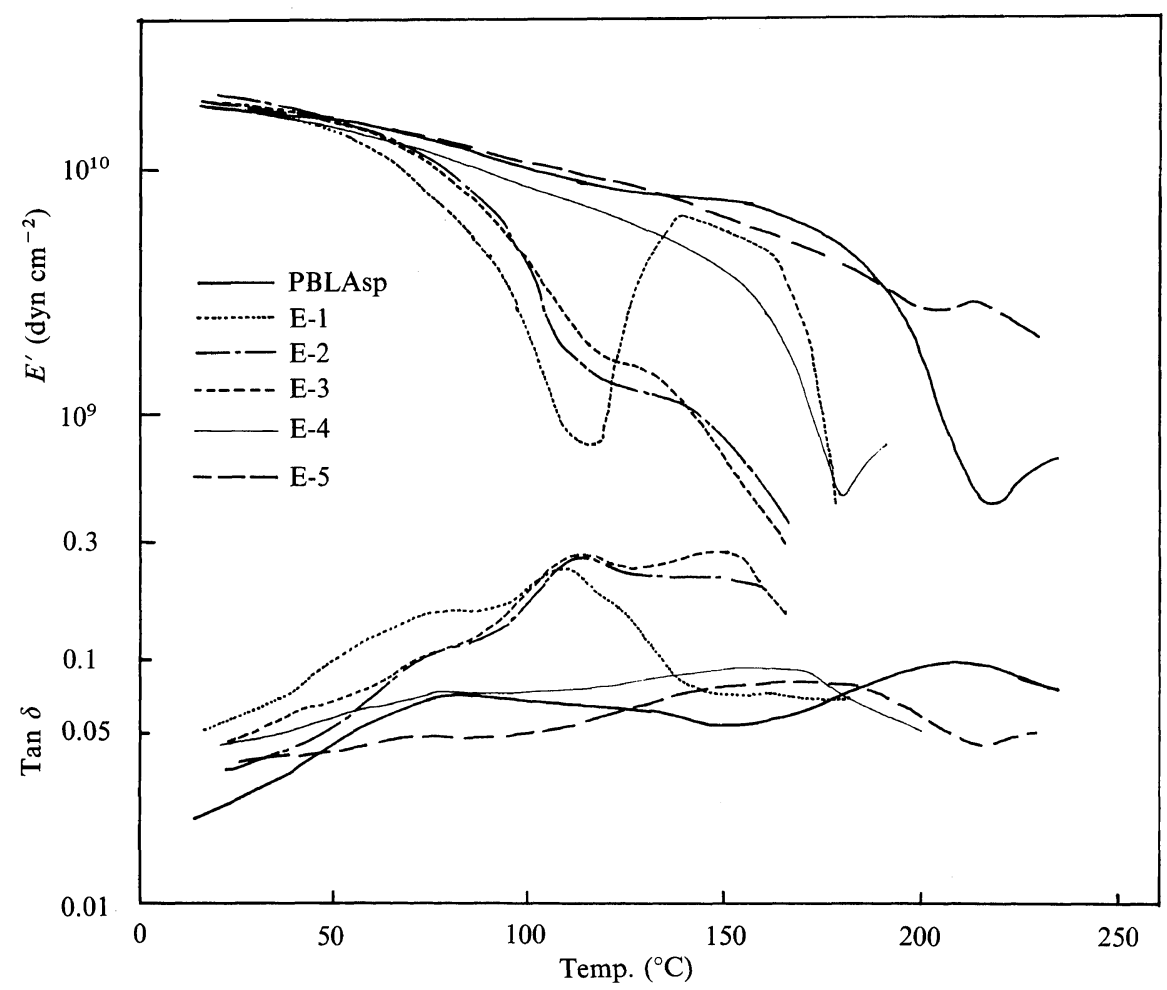

Figure 1. Dynamic modulus $E^{\prime}$ and $\tan \delta$ at $110 \mathrm{~Hz}$ as functions of temperature for PBLAsp and E-1-5:

$\longrightarrow$ PBLAsp; $\cdots \cdots$, E-1; ---·-·, E-2; -----, E-3; - - , E-4; ----, E-5.

served and succeedingly $E^{\prime}$ increases up to the value of $E^{\prime}$ of PBLAsp or E-5 in the temperature range from 100 to $135^{\circ} \mathrm{C}$. Such a $\tan \delta$ dispersion and the change in $E^{\prime}$ correspond to the $\alpha-\omega$ transition. This behavior is very similar to that observed for Bu-3-6 of copoly(butyl-L-aspartate-benzyl-Laspartate).$^{4}$ That is, the steep decrease in $E^{\prime}$ is caused by an opening of hydrogen bonds and the remarkable increase in $E^{\prime}$ is due to a partial refolding to the opposite helix sense. For a low degree of ethylation, ethyl-L-aspartate is considered to be incorporated into the $\omega$ helix of benzyl-Laspartate as described above.

For $\mathrm{E}-2,3$, the $\tan \delta$ peak also appears in the vicinity of $110^{\circ} \mathrm{C}$ and a corresponding decrease of $E^{\prime}$ is observed up to $170^{\circ} \mathrm{C}$. This fact is attributed to the expansion of the hexagonal unit cell in a temperature range from 110 to $170^{\circ} \mathrm{C}$. As described above, the expansion of the unit cell was caused both by the transition of the benzyl-L-aspartate alone into the $\omega$ helix and the absence of the transition of the ethyl-L-aspartate since stacks between benzyl and ethyl groups could not be formed for E-2, 3. That is, the E-2, 3 films consist of a mixture of $\alpha$ and $\omega$ helices having irregular junctions. Such an expansion of unit cells results in a remarkable decrease in $E^{\prime}$.

For E-4, 5, there was no transition up to $150^{\circ} \mathrm{C}$ since the benzyl-L-aspartate could not transform into a $\omega$ helix. Consequently, there was no change in thermal stability up to the $\alpha-\beta$ transformation.

In a higher temperature range $\left(170-220^{\circ} \mathrm{C}\right)$, a considerable decrease in $E^{\prime}$ for all copolyaspartates studied was observed and may correspond to the transformation into the $\beta$ form.

\section{Thermal Analysis}

DTA thermograms of copoly(ELAsp-BLAsp) are given in Figure 2. As in the case of dynamic viscoelastic behavior, thermal behavior may be classified as E-1, E-2, 3, and E-4, 5. The exothermic peak appeared only for $\mathrm{E}-1$ at $127^{\circ} \mathrm{C}$, the $\alpha-\omega$ transition temperature. The exothermic peak is 
The Structure and Properties of Copolyaspartate II.

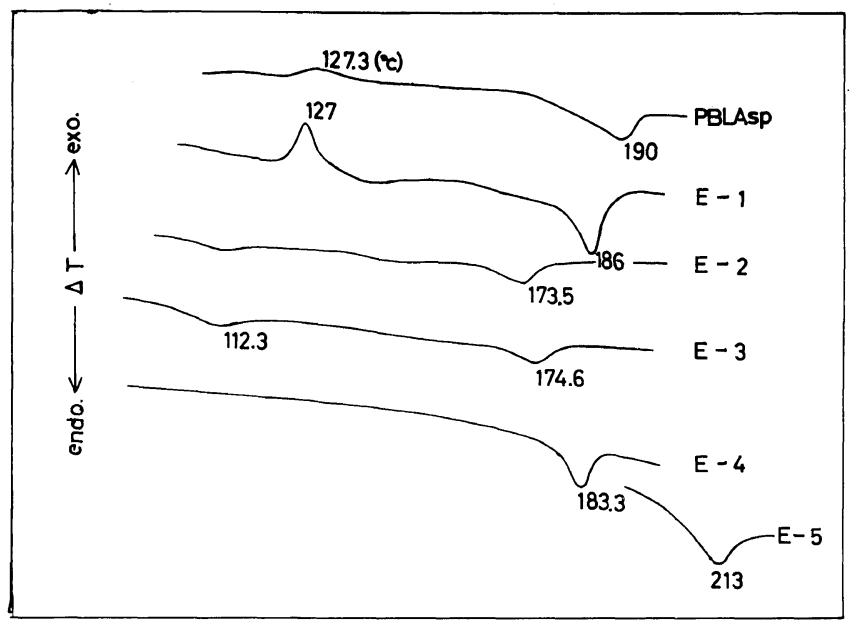

Figure 2. DTA thermograms for PBLAsp and E-1-5. The numbers in the figure are transition temperatures.

based on the transition of the benzyl-L-aspartate into the $\omega$ helix and also on the incorporation of the ethyl-L-aspartate into the $\omega$ helix, accompanied, in part, by a transformation from the right handed $\alpha$ helix to the left handed $\omega$ helix. The transition of the benzyl-L-aspartate corresponds to the transition of PBLAsp, and the incorporation of the ethyl-L-aspartate to that of copoly(butyl-L-aspartate-benzyl-L-aspartate) $(\mathrm{Bu}-3-6){ }^{4}$ It is reasonable that the enthalpy change in E-1 for the transition is larger than that of PBLAsp but smaller than that of copoly(butyl-L-aspartatebenzyl-L-aspartate) (Bu-3-6).

For E-2, 3, no exothermic peak appeared, but small endothermic peak was seen in the vicinity of $110^{\circ} \mathrm{C}$. This slight endothermic peak is considered due to an expansion into a rather large hexagonal array as was described in the X-ray diffraction analysis. Since the $\alpha-\omega$ transition does not occur even in the benzyl-L-aspartate of E-4, 5, neither exothermic nor endothermic peaks appeared below the $\alpha-\beta$ transformation temperature.

As for the transformation into the $\beta$ form, the transition temperature decreases gradually as the degree of ethylation increases (E-1). The transition temperature of E-5 was the highest for all copoly(ELAsp-BLAsp)s. Therefore, it is probable that the $\alpha$ helices of $\operatorname{poly}(\beta$-ethyl-L-aspartate) and/or copoly(ELAsp-BLAsp) with ethylation more than $\mathrm{ca} .70 \%$ are much more thermally stable than PBLAsp.
Table VII. Band positions of as-cast films $\left(\mathrm{cm}^{-1}\right)$

\begin{tabular}{cccc}
\hline & Ester C $=\mathrm{O}$ & Amide I & Amide II \\
\hline PBLAsp $(\alpha)$ & 1735 & 1663 & 1553 \\
M-1 & 1738 & 1664 & 1554 \\
M-2 & 1738 & 1664 & 1553 \\
M-3 & 1735 & 1664 & 1553 \\
M-4 & 1738 & 1664 & 1553 \\
\hline
\end{tabular}

Table VIII. Band positions of films annealed at $150^{\circ} \mathrm{C}\left(\mathrm{cm}^{-1}\right)^{\mathrm{a}}$

\begin{tabular}{cclc}
\hline & Ester C $=\mathrm{O}$ & Amide I & Amide II \\
\hline PBLAsp $(\omega)$ & 1730 & 1676 & 1533 \\
M-1 & $1727^{\text {sh }}$ & $1666^{\text {sh }}$ & 1534,1550 \\
M-2 & $1726^{\text {sh }}$ & $1665^{\text {sh }}$ & 1535,1550 \\
M-3 & 1735 & 1664 & 1553 \\
M-4 & 1737 & 1664 & 1553 \\
\hline
\end{tabular}

a sh, shoulder is included.

Table IX. Band positions of films annealed at $210^{\circ} \mathrm{C}\left(\mathrm{cm}^{-1}\right)$

\begin{tabular}{cccc}
\hline & Ester C=O & Amide I & Amide II \\
\hline PBLAsp $(\beta)$ & 1725 & 1634 & 1530 \\
M-1 & 1735 & 1635 & 1531 \\
M-2 & 1734 & 1636 & 1531 \\
M-3 & 1736 & 1635 & 1529 \\
M-4 & 1735 & 1635 & 1530 \\
\hline
\end{tabular}




\section{Copoly (methyl-L-aspartate-benzyl-L-aspartate)}

Infrared Absorption Spectroscopy

Characteristic band positions are given in Table VII for the as-cast films, in Table VIII for the films annealed at $150^{\circ} \mathrm{C}$, and in Table IX for the films annealed at $210^{\circ} \mathrm{C}$. Band positions of the as-cast films of copoly(methyl-L-aspartate-benzyl-L-aspartate) (copoly(MLAsp-BLAsp)) show almost the same values as PBLAsp. Hence, conformation of copoly(MLAsp-BLAsp) always takes on a left handed $\alpha$ helix, irrespective of the degree of methylation. The results obtained here agree well with the results in solution by Bradbury et al. ${ }^{2,3}$

Band positions of films annealed at $150^{\circ} \mathrm{C}$ are classified as M-1, 2 and M-3, 4. The Amide II bands of M-1, 2 indicate the existence of both the $\alpha$ and $\omega$ helices. That is, the benzyl-L-aspartate in copoly(MLAsp-BLAsp) transformed into the $\omega$ helix by annealing with the methyl group remaining in the $\alpha$ helix, as in the case of the E-2, 3 films annealed at $150^{\circ} \mathrm{C}$ of copoly(ELAsp-BLAsp). Thus, M-1, 2 is concluded to be in mixture of $\alpha$ and $\omega$ helices above $150^{\circ} \mathrm{C}$. On the other hand, $\mathrm{M}-3,4$ undergoes no change and is the same as the as-cast films. Hence neither the benzyl-L-aspartate nor the ethyl-Laspartate transformed into the $\omega$ helix but remained in the $\alpha$ helix form. This phenomenon is the same as that of the E-4, 5 films annealed at $150^{\circ} \mathrm{C}$. All copoly(MLAsp-BLAsp)s transformed into the $\beta$ form by annealing at $210^{\circ} \mathrm{C}$ (especially see Amide I in Table IX).

\section{$X$-Ray Diffraction Analysis}

The spacings observed in X-ray diffraction photographs of all copoly(MLAsp-BLAsp)s are given in Table $\mathrm{X}$. The spacings of the as-cast films of this copolyaspartate become shorter in propor-

Table X. Spacings $(\AA)$ observed in X-ray diffraction photographs of PBLAsp and copoly(MLAsp-BLAsp)

\begin{tabular}{cccc}
\hline & $\begin{array}{c}\text { As-cast } \\
\text { films }\end{array}$ & $\begin{array}{c}\text { Films } \\
\text { annealed } \\
\text { at } 150^{\circ} \mathrm{C}\end{array}$ & $\begin{array}{c}\text { Films } \\
\text { annealed } \\
\text { at } 210^{\circ} \mathrm{C}\end{array}$ \\
\hline PBLAsp & 13.2 & 13.9 & 17.1 \\
M-1 & 13.2 & $13.1(14.1)$ & 16.1 \\
M-2 & 12.4 & 14.4 & 15.7 \\
M-3 & 11.6 & 11.6 & - \\
M-4 & 10.7 & 10.8 & - \\
\hline
\end{tabular}

tion to the degree of methylation and this trend is much more remarkable than in copoly(ELAspBLAsp) and copoly(butyl-L-aspartate-benzyl-Laspartate).

In the case of the M-1 films annealed at $150^{\circ} \mathrm{C}$, the crystallinity of M-1 was somewhat high and another weak diffraction peak appeared, corresponding to the spacing of $14.1 \AA$ as shown in parenthesis in Table X. This film is considered to consist of a mixture of the $\alpha$ and $\omega$ helices based on the IR study described above. In fact, the spacing (13.1 $\AA$ ) nearly corresponds to the $\alpha$ helix and the material, which transformed, in part, into the $\omega$ helix, gave a spacing of $14.1 \AA$. The M-2 films annealed at $150^{\circ} \mathrm{C}$ predominantly exhibited the $\omega$ helix and virtually no spacings corresponding to the $\alpha$ helix were seen. The M-3, 4 films did not change by annealing but still remained the same as the ascast films. Therefore, no transition appeared up to $150^{\circ} \mathrm{C}$. This fact agrees well with the IR results mentioned above.

The M-1, 2 films annealed at $210^{\circ} \mathrm{C}$ gave the intersheet spacing of the $\beta$ form and the M-3, 4 films gave no diffraction. However, all the samples had interchain spacings of the $\beta$ form, $4.6-4.7 \AA$. Therefore, all the samples were found to transform into the $\beta$ form, in accordance with the results of IR absorption spectroscopy.

\section{Dynamic Viscoelastic Behavior}

The dynamic modulus $E^{\prime}$ and $\tan \delta$ at $110 \mathrm{~Hz}$ are shown as functions of temperature in Figure 3. Viscoelastic behavior may also be classified as that for M-1, 2 and M-3, 4.

The $\tan \delta$ peak appeared near $100^{\circ} \mathrm{C}$ for M-1, 2 and a corresponding decrease in $E^{\prime}$ was observed, as with E-2, 3. This behavior is explained in terms of the $\alpha-\omega$ transition of the benzyl-L-aspartate alone in a helix.

Since the M-3, 4 films are thermally stable, no transition was observed by the method of the dynamic viscoelasticity up to $150^{\circ} \mathrm{C}$. However, $E^{\prime}$ decreased slightly near $200^{\circ} \mathrm{C}$ and a corresponding broad $\tan \delta$ peak appeared, possibly due to the transformation of the $\alpha$ helix into the $\beta$ form.

\section{Thermal Analysis}

DTA thermograms of copoly(MLAsp-BLAsp) are given in Figure 4. Thermal behavior is classified as that for M-1, 2 and M-3, 4. The thermograms of $M-1,2$ exhibited two endothermic peaks near $110^{\circ} \mathrm{C}$ and $170^{\circ} \mathrm{C}$. The lower peak was at- 
The Structure and Properties of Copolyaspartate II.

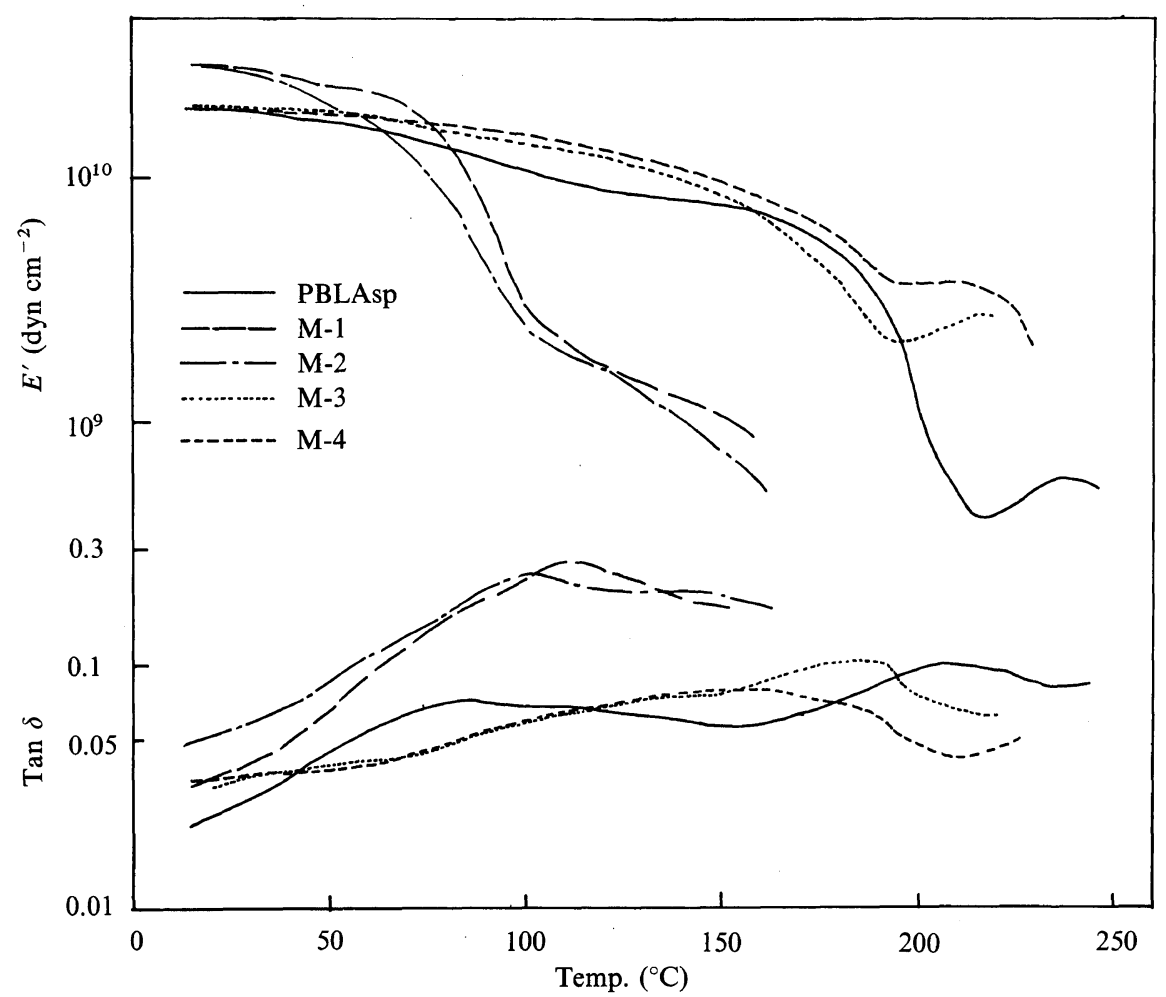

Figure 3. Dynamic modulus $E^{\prime}$ and $\tan \delta$ at $110 \mathrm{~Hz}$ as functions of temperature for PBLAsp and M-1-

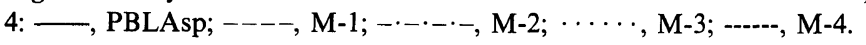

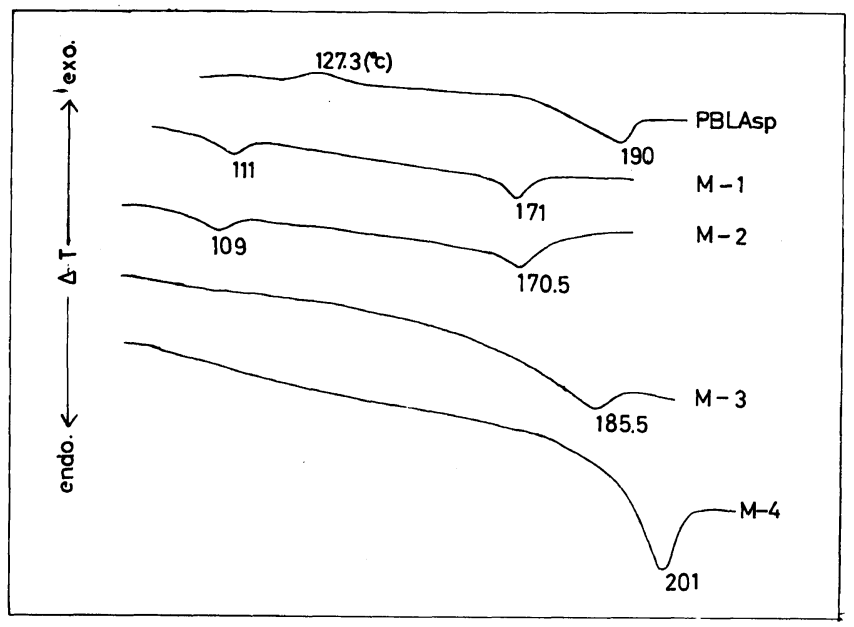

Figure 4. DTA thermograms for PBLAsp and M-1-4. The numbers in the figure are transition temperatures. 
tributed to the expansion of the hexagonal array caused by the transition of only the benzyl-L-aspartate into the $\omega$ helix. The higher peak was due to the transformation into the $\beta$ form. Similar behavior was noted for the E-2, 3 films of copoly(ELAsp-BLAsp).

The thermograms of $\mathrm{M}-3,4$ exhibited a single endothermic peak corresponding to the $\alpha-\beta$ transformation. The $\alpha-\beta$ transformation temperature lowered gradually with an increasing degree of methylation, reflecting instability of the helix comprised of a mixture of $\alpha$ and $\omega$ helices, but it intended to raise the transformation temperature with further increasing degree of methylation. The transition temperature of the $\alpha-\beta$ transformation for M-4 was lower than that for E-5, although the degree of methylation of the former was higher than that of the latter. Therefore, the $\alpha$ helix of $\operatorname{poly}(\beta$ ethyl-L-aspartate) is suggested to be much more thermally stable than that of $\operatorname{poly}(\beta$-methyl-Laspartate). The $\alpha$ helices of both poly $(\beta$-methyl-Laspartate) and $\operatorname{poly}(\beta$-ethyl-L-aspartate) are also expected to be much more stable than the $\omega$ helix of PBLAsp.

\section{REFERENCES}

1. E. M. Bradbury, A. R. Downie, A. Elliott, and W. E. Hanby, Proc. R. Soc. London, Ser. A, 259, 110 (1960).

2. E. M. Bradbury, B. G. Carpenter, and H. Goldman, Biopolymers, 6, 837 (1968).

3. E. M. Bradbury, B. G. Carpenter, and R. M. Stephens, Biopolymers, 6, 905 (1968).

4. Y. Tsujita, M. Fukagawa, and I. Uematsu, Polym. J., 14, 773 (1982). 